\title{
Annual Technical Progress Report - West Hackberry Tertiary Project
}

\author{
Annual Report \\ September 3, 1996 - September 2, 1997 \\ By:
Travis Gillham; Bruce Cerveny; Allen Fornea
}

Work Performed Under Contract No.: DE-FC22-93BC14963

\author{
For \\ U.S. Department of Energy \\ Office of Fossil Energy \\ Federal Energy Technology Center \\ P.O. Box 880 \\ Morgantown, West Virginia 26507-0880
}

By

Amoco Energy Group North America

150 West Warrenville Road

Naperville, Illinois 60566 


\section{Disclaimer}

This report was prepared as an account of work sponsored by an agency of the United States Government. Neither the United States Government nor any agency thereof, nor any of their employees, makes any warranty, express or implied, or assumes any legal liability or responsibility for the accuracy, completeness, or usefulness of any information, apparatus, product, or process disclosed, or represents that its use would not infringe privately owned rights. Reference herein to any specific commercial product, process, or service by trade

name, trademark, manufacturer, or otherwise does not necessarily constitute or imply its endorsement, recommendation, or favoring by the United States Government or any agency thereof. The views and opinions of authors expressed herein do not necessarily state or reflect those of the United States Government or any agency thereof. 


\title{
ANNUAL TECHNICAL PROGRESS REPORT (9/3/96-9/2/97) (Draft Version)
}

\section{WEST HACKBERRY TERTIARY PROJECT}

Cooperative Agreement No. DE-FC22-93BC14963--16

\author{
Amoco Production Company
}

Date of Report: 9/30/97

Award Date: 9/3/93

Anticipated Completion Date: 3/31/97 (Budget Period 1)

Government Award: $\$ 6,017,500$ (Budget Period 1)

Program Manager: Travis H. Gillham

Principal Investigator: Travis H. Gillham (with Bruce Cerveny \& Allen Fornea)

Technical Project Officer: Jerry F. Casteel

Reporting Period: 9/3/96-9/2/97 (4th Year of Budget Period 1) 


\section{Annual Technical Progress Report (9/3/96-9/2/97) \\ West Hackberry Tertiary Project}

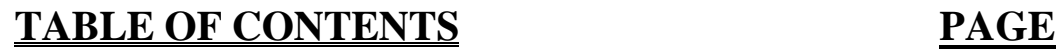

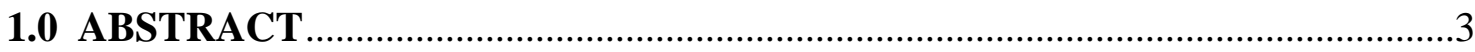

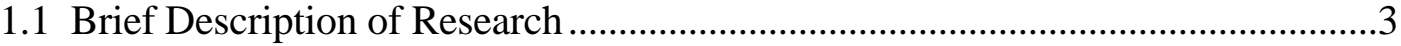

1.2 Summary of Key Results and Conclusions .......................................................... 3

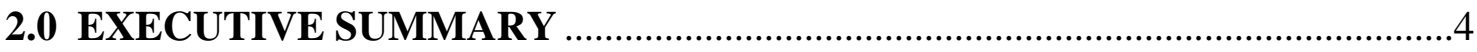

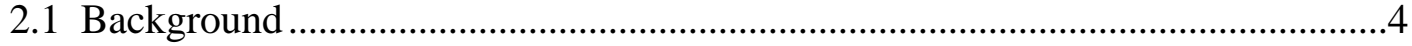

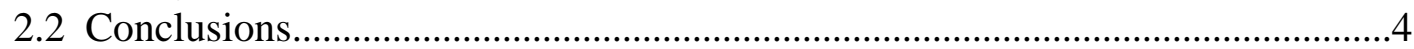

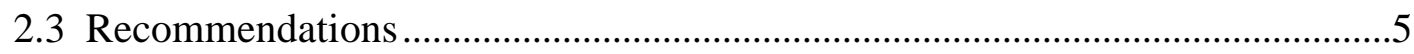

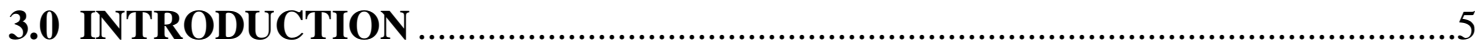

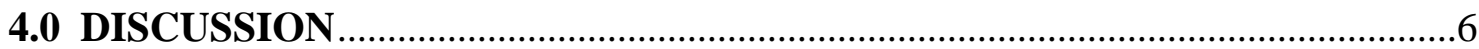

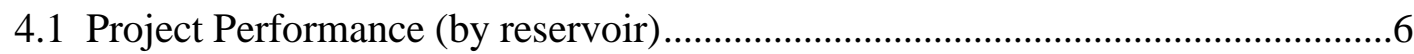

4.1.1 Fault Block IV on the West Flank (WH Cam C RI SU)..........................6

4.1.2 Fault Block II on the West Flank (WH Cam C RI SU) .............................7

4.1.3 Low Pressure Cam C Reservoir on the North Flank ..................................7

4.1.4 Low Pressure Bol 3 Reservoir on the North Flank ...................................8

4.2 Economics of Air Injection in Low Pressure Reservoirs .....................................8

4.3 Operation of Surface Air Injection Facilities....................................................

4.4 Operation of Surface Production Facilities ....................................................... 10

4.5 Well Workovers, Repairs, Recompletions and Conversions ............................10

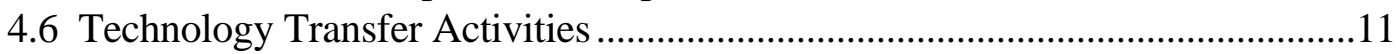

\section{APPENDIX}

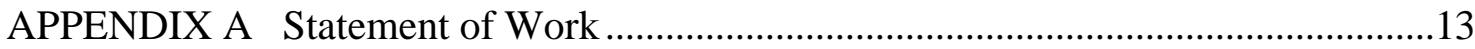

\section{FIGURES AND TABLES}

$\underline{\text { PAGE }}$

Plot of Cumulative Air Injected vs. Time ........................................................................19

Plot of Bottom Hole Pressure versus Time (west flank)...............................................20

Plot of Air Injection Rates and Surface Injection Pressures for the GLD No. 51...........21

Production Plot for the North Flank Cam C Reservoir ...............................................22

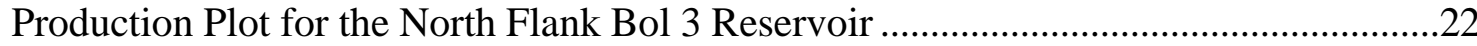

Combined Production Plot for Both North Flank Reservoirs.......................................23

Sample Economics for Low Pressure Air Injection (using W. Hackberry results) .........23

Schematic Cross-Section of North Flank Air Injection Reservoir..................................24

Structure Map for the Top of the Cam C-1 (north flank-WH Cam C RB SU) ................25

Structure Map for the Top of the Cam C-1 (west flank-WH Cam C RI SU)..................26 


\section{Annual Technical Progress Report (9/3/96-9/2/97) \\ West Hackberry Tertiary Project}

\section{$\underline{\text { 1.0 ABSTRACT }}$}

\subsection{Brief Description of Research}

The West Hackberry Tertiary Project is a field test of the concept that air injection can be combined with the Double Displacement Process to produce a tertiary recovery process that is both low cost and economic at current oil prices. The Double Displacement Process is the gas displacement of a water invaded oil column for the purpose of recovering tertiary oil by gravity drainage. In reservoirs with pronounced bed dip such as those found in West Hackberry and other Gulf Coast salt dome fields, reservoir performance has shown that gravity drainage recoveries average $80 \%$ to $90 \%$ of the original oil in place while waterdrive recoveries average $50 \%$ to $60 \%$ of the original oil in place. The target for tertiary oil recovery in the Double Displacement Process is the incremental oil between the $50 \%$ to $60 \%$ waterdrive recoveries and the $80 \%$ to $90 \%$ gravity drainage recoveries.

In previous field tests, the Double Displacement Process has proven successful in generating tertiary oil recovery. The use of air injection in this process combines the benefits of air's low cost and universal accessibility with the potential for accelerated oil recovery from the combustion process. If successful, this project will demonstrate that utilizing air injection in the Double Displacement Process will result in an economically viable tertiary process in reservoirs (such as Gulf Coast salt dome reservoirs) where any other tertiary process is presently uneconomic.

\subsection{Summary of Key Results and Conclusions}

Air injection on the west flank began in November of 1994. Although west flank air injection has increased reservoir pressure by 500 pounds per square inch (psi), production response has not yet occurred. The gas cap on the west flank has not expanded sufficiently to push the oil rim down to the nearest downstructure well. Continued air injection is expected to further expand the gas cap and thereby bring about oil production.

To spread project risk among multiple reservoirs, the project was expanded in 1996 to include air injection in low pressure reservoirs on the north flank of the field. The project reservoirs on the west flank are much higher pressure (2500-3300 psi) than the project reservoirs on the north flank (300-600 psi). Air injection began on the north flank in July of 1996. While west flank air injection has not yet yielded oil production, air injection in the first two low pressure north flank reservoirs generated an almost immediate increase in oil production. Between July of 1996 and July of 1997, air injection increased north flank oil production by 58,500 barrels or $61 \%$ above the normal decline. In addition, an analysis of north flank performance indicates that low pressure air injection can be economically profitable at current oil prices. 
While air injection is beginning to demonstrate success in the low pressure north flank reservoirs, continued air injection will be required to generate production response on the west flank of the field. During the upcoming year, air injection will be split between the higher pressure west flank reservoir and several low pressure north flank reservoirs with the ultimate goal to maximize production response in as many reservoirs as possible.

\subsection{EXECUTIVE SUMMARY}

\subsection{Background}

The following report is the Annual Technical Progress Report for the fourth year of the West Hackberry Tertiary Project and covers the time period from September 3, 1996 to September 2, 1997. The West Hackberry Tertiary Project is one of four mid-term projects selected by the United States Department of Energy (DOE) as part of the DOE's Class 1 Program for the development of advanced recovery technologies in fluvial dominated deltaic reservoirs.

Over an 106 month funding period from September 3, 1993 to July 2, 2002, Amoco and the DOE are implementing a field test of the theory that air injection can be combined with the Double Displacement Process to create a tertiary oil process that is economically viable for the domestic oil industry. Air injection on the west flank of the field is testing the process in higher pressure (2500-3300 psi) reservoirs which have watered out. Although the project originally targeted the west flank of the field, Amoco and the DOE agreed to expand the project to the north flank during 1996. The low pressure north flank reservoirs exhibit slow water encroachment, possess low pressure gas caps and contain thin oil rims. Injection on the north flank is testing the process in low pressure (300-600 psi) reservoirs that are approaching depletion.

As part of the project, the Petroleum Engineering Department at Louisiana State University (LSU) has been subcontracted to provide independent study and technology transfer support. The Statement of Work for the West Hackberry Tertiary Project is included as Appendix A. West Hackberry is a salt dome oil field located in Southwestern Louisiana about 30 miles southwest of Lake Charles, Louisiana.

\section{$\underline{2.2 \text { Conclusions }}$}

The following conclusions have been generated during the third year of the project:

1) West flank reservoir pressure has increased by 500 psi as a result of air injection and confirms the original geologic picture.

2) Oil production has not yet occurred on the west flank since the oil rim has not moved sufficiently downstructure to reach the first producing well. The gas cap has not expanded enough to push oil rim down to the most upstructure producing well for the following reasons: a) a lack of sufficient volume of air injected, b) the large size of the reservoir, c) the high reservoir pressure which inhibits the growth of the gas cap and d) uncertainty as to the pre-injection structural location of the oil rim. 
3) Air injection in each of two low pressure north flank oil reservoirs has generated almost immediate and promising production response. An economic analysis of north flank low pressure air injection indicates that this process is economic at current oil prices.

\subsection{Recommendations}

The following recommendations are presented for the upcoming year:

1) Divide air injection between the high pressure west flank reservoirs and several low pressure north flank reservoirs with the ultimate goal to maximize production response in as many reservoirs as possible.

2) Monitor reservoir performance with production data, bottom hole pressure surveys, well tests and produced oil, gas and water analyses.

3) Utilize production response to guide the timing for workovers and to guide the injection rates for each reservoir.

4) Continue the aggressive plan of technology transfer initiated during 1997 which emphasizes publicizing key learnings obtained from ongoing field operations.

\section{$\underline{\text { 3.0 Introduction }}$}

In the West Hackberry Tertiary Project, air is injected into high pressure (2500-3300 psi) watered out oil reservoirs on the west flank and into low pressure (300-600 psi) north flank oil reservoirs that are nearing depletion. In both situations, air injection is combined with the Double Displacement process in an attempt to generate an economically viable tertiary recovery process for Gulf Coast oil reservoirs with pronounced bed dip. The Double Displacement Process is the gas displacement of a water invaded oil column for the purpose of recovering tertiary oil by gravity drainage. In West Hackberry Field, gravity drainage recoveries average $80 \%$ to $90 \%$ of the original oil in place while waterdrive recoveries average $50 \%$ to $60 \%$ of the original oil in place. The target for tertiary oil recovery in the Double Displacement Process is the incremental oil between the $50 \%$ to $60 \%$ waterdrive recoveries and the $80 \%$ to $90 \%$ gravity drainage recoveries.

For air injection to work successfully with the Double Displacement Process, the reservoir temperature must be high enough for oxygen to be consumed through combustion with the reservoir oil. Amoco has performed laboratory tests which prove that West Hackberry oil will spontaneously combust with oxygen in the pore space. The combustion of oxygen in the reservoir alleviates concerns relating to the presence of oxygen in the reservoir or production equipment. Oxygen in the reservoir can form viscous emulsions hindering the flow of oil in the well and in the production equipment. Oxygen that reaches the producing wells can also produce corrosion and or explosions in the production equipment.

In the higher pressure (2500-3300 psi) west flank reservoirs, the mechanics of the tertiary process involve: 1) injecting air into the crest of a watered out oil reservoir in order to fill the reservoir with a gas from the top down, 2) as the reservoir fills with air, oxygen is 
consumed through spontaneous combustion, 3) oil and water drain toward the base of the structure through gravity segregation and gravity drainage, and 4) tertiary oil, which previously had been trapped as a residual oil saturation, is now produced in downstructure wells. In this case, the economic potential of the project is enhanced by the low cost associated with using air as the injection gas.

On the north flank of West Hackberry, low pressure (300-600 psi) oil reservoirs are found which have large low pressure gas caps, thin oil rims and slow water encroachment. In the low pressure north flank reservoirs, air injection can increase oil recovery by: 1) pushing the oil rim downstructure to the structural location of existing wellbores, 2) repressurizing the reservoir and 3) obtaining tertiary oil recovery through the Double Displacement Process in the same manner as described in the preceding paragraph. Although injection of nitrogen, carbon dioxide and natural gas have been utilized to increase oil recovery in Gulf Coast reservoirs in the past, this project is unique in the use of air as the injection gas.

\section{$\underline{4.0}$ Discussion}

\section{$\underline{4.1 \text { Project Performance (by reservoir) }}$}

\subsubsection{Fault Block IV on the West Flank (WH Cam C RI SU)}

On Page 26 is a structure map for the top of the Cam C-1 Sand on the west flank of West Hackberry Field. As noted on the structure map, the Gulf Land D (GLD) No. 51 serves as the air injector for Fault Block IV and is located near the crest of the structure. From November 17, 1994 to August 1, 1997, 1522 million standard cubic feet (MMSCF) of air has been injected into the GLD No. 51. On Page 19 is a plot of cumulative air injected versus time.

In Fault Block IV, reservoir pressure has increased about 500 psi since the start of air injection. The GLD No. 44 (Cam C-1,2), GLD No. 45 (Cam C-1,2) and GLD No. 52 (Cam $\mathrm{C}-1,2)$ are future producing wells currently completed in the project interval in Fault Block IV. All of these wells have seen an increase in bottom hole pressure as a result of air injection. A plot of bottom hole pressure versus time is included on Page 20.

Oil production has not yet occurred in Fault Block IV since the oil rim has not moved sufficiently downstructure to reach the closest producing well, the GLD No. 44. A review of a recent 3-D seismic survey suggests that there is no evidence of reservoir separation between the GLD No. 51 (injector) and the GLD No. 44. The fact that the GLD No. 44 has not produced nitrogen suggests that the flood is proceeding as planned in a gravity stable manner.

The lack of production response in Fault Block IV can be attributed to the large size of the reservoir, the high reservoir pressure (3000 psi) which inhibits the growth of the gas cap, uncertainty as to the pre-injection location of the oil rim and an insufficient volume of air 
injected to date. Plans are to continue air injection in the GLD No. 51 in order to maintain the growth of the upstructure gas cap and to bring about oil production in the GLD No. 44. The reservoir model suggests that the gas cap will require injection of an additional 800 MMSCF of air before sufficient the oil rim reaches the GLD No. 44.

The GLD No. 51 serves as the air injector for Fault Block IV. In August of 1997, the GLD No. 51 plugged up with formation sand and magnetite (Fe3O4). Coiled tubing was used to wash the sand out and hydrochloric acid was pumped to dissolve the magnetite. Although injection was restarted in September, injection pressure is higher than normal due to continued plugging of the wellbore by magnetite and formation sand. A plot of injection rates and pressures for the GLD No. 51 is included on Page 21.

\section{$\underline{\text { 4.1.2 Fault Block II on the West Flank (WH Cam C RI SU) }}$}

In Fault Block II, the Watkins No. 18 most recently served as the air injector and the GLD No. 56 served as the downstructure future producer. Originally, the Watkins No. 16 was the air injector for Fault Block II. When the Watkins No. 16 experienced casing collapse during a workover, the well was temporarily abandoned. Both the GLD No. 56 and the Watkins No. 18 exhibited premature nitrogen breakthrough without evidence of oil production. The nitrogen breakthrough is believed to have been caused by the nitrogen preferentially flowing through a high permeability interval near the top of the Cam C-1. In addition, Fault Block II has a lower bed dip (23 degrees) than other reservoirs involved in the project which is expected to cause Fault Block II to be more susceptible to premature nitrogen breakthrough.

In June of 1997, an attempt was made to produce from the Watkins No. 18 by flowing the well to a tank. The previously injected air was expected to have pushed the oil rim down to the injection well thereby giving the Watkins No. 18 the potential to produce oil. As a valve was being opened to flow the well, a small detonation resulted in the tubing pressure increasing sharply and immediately falling off while smoke flowed from the flowline into the tank. The wellhead and flowline became extremely hot. The well was immediately shut in and a chain and lock was placed on the wellhead. The incident is still under investigation.

\subsubsection{Low Pressure Cam C Reservoir on the North Flank}

To spread project risk among multiple reservoirs, Amoco and the DOE agreed to expand the project to include air injection in low pressure reservoirs on the north flank of the field. The low pressure north flank reservoirs exhibit slow water encroachment, possess low pressure gas caps and contain thin oil rims. In the low pressure north flank reservoirs, air injection can increase oil recovery by: 1) pushing the oil rim downstructure to the structural location of existing wellbores, 2) repressurizing the reservoir and 3) obtaining tertiary oil recovery through the Double Displacement Process.

Air injection began on the north flank in a low pressure (300-600 psi) Cam C oil reservoir during July of 1996. A schematic cross-section of the reservoir is included on Page 24. The SL 42 No. 155 serves as the air injector in the gas cap. A structure map for the top of 
the Cam C-1 is included on Page 25. To date, four producing wells have shown an increase in oil production as a result of air injection in the Cam $\mathrm{C}$ sand. A composite production plot for the four producing wells in the north flank Cam $\mathrm{C}$ sand is included on Page 22. As shown on the production plot, air injection has resulted in increased oil production and reduced water cut.

\subsubsection{Low Pressure Bol 3 Reservoir on the North Flank}

In December of 1996, air injection was extended to a second low pressure north flank reservoir, the Bol 3 sand. As with the Cam $\mathrm{C}$ reservoir, the Bol 3 reservoir has low reservoir pressure, a thin oil rim, steep bed dip and slow water encroachment. To date, oil production has increased in two wells since the start of air injection. A composite production plot for the two producing wells in the Bol 3 north flank reservoir is included on Page 22.

\subsection{Economics of Air Injection in Low Pressure Reservoirs}

West Hackberry performance can be used as a case study to demonstrate the profitability of air injection in low pressure reservoirs. The operating cost aspect of the analysis is was more difficult to determine since it is difficult to separate the costs associated with low pressure air injection from the cost related to high pressure air injection. Rather than trying to estimate the cost distribution, a price quote was obtained from a compressor operating company for the purchase of compressed air at 1000 psi. The following economic analysis is based upon a scenario which utilizes the purchase of compressed air on site combined with the incremental West Hackberry production response.

In an air injection project where compressed air is provided for a fixed price, limited capital expenditures are still required for injection lines, converting upstructure wells to injectors, control systems and oxygen monitors. Operating costs assume that the compressor operating company is providing 2000 MSCFD of compressed air at a price of $\$ 0.49 / \mathrm{MSCF}$ (including the cost of fuel gas at $\$ 2.00 / \mathrm{MMBTU}$ ).

The capital investment for lines and control systems to transport air (at $1000 \mathrm{psi}$ ) from the contractor's facilities to the two air injectors is estimated to be $\$ 280,000$. The total cost to convert two shut-in producers to air injectors was $\$ 40,000$. Therefore, the total initial capital investments downstream of the air compressor would have been $\$ 320,000$. These costs are applicable to West Hackberry Field. Depending upon field operating conditions, the magnitude of investments necessary to implement a low pressure air injection project could vary greatly from field to field.

From July of 1996 to July of 1997, 392,000 MSCF of air was injected into two low pressure reservoirs, the $\mathrm{Cam} \mathrm{C}$ and the Bol 3. For that time period, air injection generated 58,500 barrels of incremental oil production above normal decline. A composite production plot for the Cam $\mathrm{C}$ and the Bol 3 can be found on Page 23. Assuming an average oil price of $\$ 20$ per barrel, the 58,500 barrels of incremental oil would have generated $\$ 853,000$ in cash receipts after subtracting one sixth royalty and $12.5 \%$ severance tax. Reducing the $\$ 853,000$ by $\$ 192,000$ for the cost of compressed air (392 
MMSCF at $\$ 0.49 / \mathrm{MSCF}$ ), $\$ 20,000$ for acid treatments and $\$ 320,000$ for capital investments yields a before tax positive incremental cash flow of $\$ 321,000$.

This economic analysis indicates that low pressure air injection in a Gulf Coast salt dome field can be profitable and even pay out initial investments in less than a year. A summary of the economic analysis is noted on Page 24.

\subsection{Operation of Surface Air Injection Facilities}

Air compression consists of an Atlas-Copco ZR-6 two stage oil-less screw compressor in series with an Ariel JGK-4 five stage reciprocating compressor. Air is compressed from atmospheric pressure to $4000 \mathrm{psig}$. Both compressors are driven by Waukesha GL series lean burn natural gas engines. The air is then distributed to the west flank GLD No. 51 injection well through a high pressure pipeline. At the GLD No. 51 the flow is split and the air which is not injected in the GLD No. 51 takes a pressure drop across a pressure reducing valve and is distributed to the north flank low pressure injection wells through a low pressure pipeline system.

Downtime over the last year was caused by one significant mechanical failure, nitrogen contaminated fuel gas and injection well impairment. The mechanical failure occurred on the Waukesha 5108GL screw compressor engine in the fourth quarter of 1996. A leaking packing ring on a cylinder sleeve allowed communication of the cylinder coolant with the crankcase oil causing water contamination of the oil. When the cylinder and piston assembly was removed and inspected, the top of the piston showed indications of detonation. The cylinder sleeve had no damage or abnormal wear and was installed with new packing rings and a new piston. Upon startup, after the cylinder repair, coolant was still being lost. Further inspection found a cracked water cooled exhaust manifold which allowed coolant to be lost through the exhaust. A new exhaust manifold was installed. Total downtime for the diagnosis and repair of the cylinder, piston, and exhaust manifold was 9 days. Subsequent inspection of the piston by Waukesha confirmed the detonation. The timing and the fuel mixture were reset to prevent further detonation.

By the second quarter of 1997, fuel gas was becoming badly contaminated by nitrogen production from the north flank producing wells responding to air injection. The British Thermal Unit (Btu) content of the fuel gas was dropping due to the nitrogen content. The low emission engines would not run fully loaded on the lower Btu gas and were shutting down. North flank producing wells were tested to determine which wells were producing the high nitrogen gas. The high nitrogen producers were shut in until the gas system was cleaned up. The compressor fuel systems were adjusted to run on the lower btu fuel gas at a reduced load. Simultaneously, increasing injection well pressures contributed to lowering the injection rates. Finally, the injection wells pressured up to a point that prevented further injection and the system was shut down to repair the wells. The injection wells were repaired in the third quarter of 1997 and air injection resumed but at reduced rates due to impaired injectivity. 


\subsection{Operation of Surface Production Facilities}

As discussed above, the north flank wells responding to air injection are producing gas with increasing nitrogen content. The result is a low Btu gas that is noncommercial and causing problems with the field gas quality. To solve this problem, a flare stack is presently being installed to combust this noncommercial gas. The gas produced from the SL 42 No. 220 well, which is the highest oil producer at 120 BOPD, contained the highest amounts of nitrogen and carbon dioxide. The SL 42 No. 220 is the highest contributor of the nitrogen causing the low Btu gas. The produced gas from the SL 42 No. 220 was analyzed to be $187 \mathrm{Btu} / \mathrm{cu}$. ft. which is lower than the content for combustion without supplementing with rich gas. Therefore, an exception to flare and permission to vent was applied for and received. A separator was installed at the wellsite so that the gas could be vented off the casing. This allows the well to be produced at 120 BOPD while the flare stack is being installed. The remaining oil wells with lower nitrogen content are being produced while the gas is being tested and monitored to ensure that the system is not being contaminated with nitrogen. When installation of the flare stack is completed, this noncommercial gas will be flared.

\subsection{Well Workovers, Repairs, Recompletions and Conversions}

Only one producing well has required a repair to replace hardened steel rods resulting from corrosion (pitting from carbon dioxide). Corrosion monitoring programs are in place that utilize water samples (iron counts), corrosion coupons and electric resistance measurement probes to gather base data and to monitor for changes in producing characteristics or corrosion rates. The only appreciable increase in corrosion rate has been detected in one well, the SL 42 No. 220, which is being treated with inhibitor.

Presently, magnetite $\left(\mathrm{Fe}_{3} \mathrm{O}_{4}\right)$ fill (resulting from corrosion in tubing and flowlines) in the gravel pack screens has impaired the injectivity to varying degrees in each of the three injectors. Presently, each of threel three injectors are partially plugged. To prevent future plugging, tubing will be replaced with coated tubing (in the two injectors that have uncoated tubing) and an improved filtering system will be installed at each wellhead. The following is a discussion of workovers on two injection wells to re-establish injectivity:

\section{GLD No. 51}

In July 1996, the GLD No. 51 experienced mechanical problems downhole and air injection ceased into the wellbore. Workover operations with a workover rig were initiated to clean out fill. The permanent packer was milled and retrieved. A muleshoe assembly was run to attempt to wash out fill in the casing. Fill was encountered at 7202' (perfs: 7300'-7448') and the well was washed out to 7220'. Scale and rust were recovered in the returns. Samples were analyzed and were found to be magnetite $\left(\mathrm{Fe}_{3} \mathrm{O}_{4}\right)$.

Drilling mud was used to maintain hole stability while washing the well out to 7416'. The well was gravel packed using a screen and liner that employed high alloy metallurgy in order to prevent future corrosion. The screen is 825 incolloy wirewrap with 316L SS base pipe. The mud was displaced out and the hole was cleaned with a thinner flushed across the interval. The screen assembly was run and landed and the interval was gravel packed 
with $12 / 20$ sand. Blank pipe was extended above the formation top to $7067^{\prime}$. This was done to protect any other portions of the casing possibly damaged by exposure to $\mathrm{KCl}$ purge water/air injection. The well's injectivity was restored as a result of this workover.

\section{SL 42 No. 155}

The SL 42 No. 155 serves as the injector for the low pressure north flank Cam C reservoir. Before gassing out in an upstructure position, the SL 42 No. 155 was a gravel packed producer. Since this conversion to air injector would be without a $\mathrm{KCl}$ purge system, the decision was made to leave the existing tubulars in the wellbore. The existing tubulars consisted of 2-7/8" EUE 8RD N80 tubing and a standard screen and liner package used in the Gulf Coast, which is a SS wire wrap on $\mathrm{J}-55 / \mathrm{N}-80$ blank pipe. Air injection commenced without incident but after several months injection, pressures began rising and reached the maximum pressure limit of the north flank air flowlines, 1200 psi. Injection of 1000 gallons of $15 \% \mathrm{HCl}$ was successful in re-establishing injectivity.

After one month, injection pressure increased and injection rate decreased. Attempts to restore injection rate at lower pressure was unsuccessful by bullheading 15\% HCL this time. Coiled tubing was called out to check the screen and spot additional acid. This was successful in restoring injectivity. While the use of nitrogen and foam was was unsuccessful, the addition of $\mathrm{HCl}$ made it possible to wash out the screen and restore injection.

After several months, the injection pressure began increasing and injection rate decreased, indicating fill in the screen or damage to the formation. This time, pumping $\mathrm{HCl}$ down the tubing was unsuccessful in restoring injectivity. Coil tubing was again brought to location with the objective to clean out the screen and liner. A downhole motor twisted off and was lost in the screen while attempting to wash out fill. $\mathrm{HCl}$ was spotted and allowed to soak. This was marginally successful and the decision was made to cease clean out operations.

\subsection{Technology Transfer Activities}

The increased oil production on the north flank has facilitated a more intense program of technology transfer activities. The following technology transfer activities have occurred or will occur in the near future:

a) A brief news release on the increase in oil production in the "Technology Digest" section of the February, 1997, edition of the "Journal of Petroleum Technology."

b) On August 23, 1997, the West Hackberry Air Injection Project received the "Best of the Gulf Coast Award" in the Best Advanced Recovery Project division from the Texas Independent Producers and Royalty Owners Association.

c) On September 16, 1997, representatives from Louisiana State University (LSU), Amoco, DOE and the Petroleum Technology Transfer Council (PTTC) presented a technology transfer workshop at LSU in Baton Rouge, Louisiana, which used the West Hackberry Air Injection Project as a case study. 
d) On September 17,1997, Amoco personnel gave a presentation on the West Hackberry project to a combined meeting of the Society of Petroleum Engineers' (SPE) Westside and South Louisiana Study Groups in Houston, Texas.

e) On October 6, 1997, a paper entitled "Keys to Increasing Production Via Air Injection in Gulf Coast Light Oil Reservoirs" will be presented at the SPE Annual Technical Conference and Exhibition in San Antonio, Texas.

f) On October 17, 1997, an Amoco geologist will present a paper entitled "Air Injection Enhanced Oil Recovery and 3-D Seismic: Revitalizing an Aging South Louisiana Oil Field" at the Gulf Coast Association of Geological Societies' (GCAGS) Annual Convention in New Orleans, Louisiana.

g) During the last week of October, an article discussing the West Hackberry Air Injection Project will appear in the "Enhanced Energy Recovery News."

h) On October 30, 1997, an Amoco personnel will make a technology transfer presentation concerning West Hackberry air injection for the Texas Railroad Commission in Houston, Texas.

i) The November, 1997, issue of "World Oil" will contain an article discussing the West Hackberry Air Injection Project co-authored by Amoco and LSU personnel.

j) On January 23, 1997, an Amoco engineer will give a presentation entitled "Air Injection: Low Cost IOR for Gulf Coast Reservoirs" at a technology tranfer conference in New Orleans sponsored by LSU's Basin Research Institute.

k) An abstract has been submitted to SPE for a paper entitled "Low Cost IOR: An Update on the West Hackberry Air Injection Project." If accepted, this paper will be presented at the SPE/DOE Eleventh Symposium on Improved Oil Recovery in Tulsa, Oklahoma, on April 19-22, 1998.

\section{$\underline{\text { SI Metric Conversion Factors }}$}

bbl x 1.589873

E-01 = cubic meters

cubic feet x 2.831685

$\mathrm{E}-02=$ cubic meters

psi x 6.894757

$\mathrm{E}+00=\mathrm{kPa}$

Btu x 1.055056

$\mathrm{E}+00=\mathrm{kJ}$ 
APPENDIX A

STATEMENT OF WORK 


\title{
STATEMENT OF WORK
}

\section{WEST HACKBERRY TERTIARY PROJECT}

\author{
Amoco Production company \\ October 16, 1992
}

\section{Background and Objectives}

The goal of the West Hackberry Tertiary Project is to demonstrate the technical and economic feasibility of oil recovery using air injection in the double Displacement Process. The Double Displacement Process is the gas displacement of a water invaded oil column for the purpose of recovering oil through gravity drainage. A novel aspect of this project is the use of air as the injection fluid. This technology will be applicable to reservoirs which have both sufficient bed dip for gravity drainage and sufficient reservoir temperature for the consumption of oxygen. Numerous water-drive reservoirs associated with salt dome fields along the Gulf Coast would be potential follow-up candidates for this technology. The use of air injection in this process offer the benefits of air's excellent accessibility and low cost combined with potentially greater recovery due to the combustion process. If successful, this project will demonstrate that the use of air injection in the Double Displacement Process can economically recover oil in reservoirs where tertiary oil recovery is presently uneconomical.

Based on a preliminary project design developed prior to commencement of the project, the following basic operational information has been determined for the study: injection rates; selection of reservoirs and fault blocks; required number of producing and injection wells; requirements for new wells versus re-completing existing wells; requirements for continuous injection versus intermittent injection; assessment of the disposal of produced gases by flaring or injection into low pressure reservoirs; unitization; and the design of surface production and injection facilities. The project is designed for injection into two separate fault blocks (Fault Blocks II \& IV). In Fault Block IV, the technology will be assessed using a line of four producers at structurally equivalent positions in a heavily developed area. In Fault Block II, the technology will be assessed using a single producer in a sparsely developed area.

A description of each task associated with the project is provided below.

\section{Task 1 - Environmental Study}

It is anticipated that this project will be categorically excluded from the DOE NEPA requirements. Upon DOE certification, if this project does qualify for a categorical exclusion, this task will not be required. If this project does not quality for a categorical exclusion, then this task will involve activities, such as data collection and reporting, that are required by the DOE to meet NEPA requirements. 


\section{Task 2 - Construction of Surface Facilities}

The necessary permits required for construction of the surface facilities will be obtained. Based on the preliminary project design, Amoco will acquire the necessary equipment/facilities to inject 4-4.5 MMCFD of air at pressures greater than 4000 psi. Surface injection facilities will be installed which consist primarily of the air compressors and water purge system for the injection wells. The timing for the installation of production facilities will be tied to workovers on the producing wells conducted in Task 5 . The production facilities will consist of flowlines, possibly a Natural Gas Liquids recovery unit, and a separate-test-and-boost (STAB) facility. After separation and testing, produced fluids will be piped to Amoco's central production facility. Undesired produced gasses will be flared or injected into low pressure reservoirs.

\section{Task 3 - Conversion of Producing Wells to Injection Wells}

Two producing wells will be converted to injection wells. Initially, a single injection well will be dedicated to each of the two fault blocks. Two additional injectors (i.e. converted producing wells) may be required to improve the economics of the process. A typical workover to convert a producing well to an injector would require cleaning out the wellbore, perforating the full prospective injection interval, and completing the well with new packers, tubing, and wellhead (i.e. valves, etc.).

\section{Task 4 - Operations and Maintenance of Injection Facilities}

The operation of the high pressure air compressors in the injection facilities requires close attention to safety issues. Synthetic lubricants and periodic cleaning of injection equipment will be conducted to prevent the possibility of a detonation resulting from the combination of high pressure air and hydrocarbon deposits. Additionally, routine maintenance of injection equipment will be conducted to avoid the possibility of catastrophic mechanical failure. Workovers to repair injection wells will be performed on an as needed basis.

\section{Task 5 - Workovers for Monitoring and Producing Wells}

A total of 9 wells will be repaired and/or re-completed to serve as producing wells and/or monitoring wells for the project. The timing of the workovers will be dictated by the advance of the flood front. The task of monitoring the flood front is addressed in Task 6. Once the project is underway, workovers to repair producing and monitoring wells will be performed on an as needed basis.

\section{Task 6 - Production Operations}

All production operations for the project will be handled by Amoco field personnel assigned to West Hackberry Field. Produced liquids will be transported through existing collection lines to be handled at an Amoco Tank Battery. Initially, producing wells will be 
gas lifted within Amoco's field-wide gas lift system. When the produced gasses become concentrated with undesirable components (e.g. nitrogen and carbon dioxide) due to breakthrough, it will be necessary to install a separate gas lift system for the project. The separate gas lift system will require a gas lift compressor. Produced gasses will either be sold, burned as fuel, flared or re-injected into low pressure reservoirs on the north flank of the field. Booster compressors may be required to generate sufficient pressure for injection of produced gasses. A flowline will be installed to the north flank of West Hackberry Field in order to carry the produced gasses to the low pressure reservoirs in that area. Monthly production tests, at a minimum, will be performed on all producing wells. Gas analyses will be conducted periodically to monitor the composition and oxygen content of the produced gasses. Produced oil and water samples will be analyzed periodically to determine their composition and physical properties. Pulsed neutron logs, bottom hole pressure surveys, temperature surveys, and spinner surveys may be run in both producing and monitoring wells in order to assess the effectiveness of the project. Periodic replacement of surface production and injection equipment (including flowlines) may also be required due to wear and tear on these items.

\section{Task 7 - Reservoir Management}

Reservoir modeling studies will be conducted to effectively manage the project. These studies will assist in assessing the following: distribution of injection volumes; timing of repairs and recompletions; and the determination of monitoring schemes and schedules. Amoco's "THERM" reservoir model will be used to history match reservoir performance and to predict future reservoir performance. Specialized combustion tests will be conducted at Amoco's Combustion Laboratory in Tulsa, Oklahoma to assist in monitoring and predicting the performance of the project. Reservoir fluid property analyses will be conducted to calibrate the reservoir model. The results of reservoir management will be continually documented and reported in a manner consistent with the DOE reporting requirements and technology transfer needs of the project.

\section{Task 8 - Louisiana State University Technology Transfer}

A yearly Amoco grant will be provided to the Petroleum Engineering Department at Louisiana State University (LSU). LSU will study various aspects of the project and report their findings. LSU will publish and make industry presentations on all results from their analyses. Amoco plans to provide LSU with all pertinent data and information from the project. Examples of typical data and information that will be made available to LSU include the following: individual well production rates; individual well injection rates; structure maps; net pay isopachs; core data; well logs; gas analyses; and fluid property data.

\section{Task 9 - Amoco Technology Transfer}

Amoco will assess the technical and economic feasibility of Double Displacement Process

based on the data and information acquired from the project. These results will be 
documented and submitted to various technical conferences for presentation and/or publication. Since the Double Displacement Process will probably have its greatest applicability to salt dome fields along the Gulf Coast, Amoco personnel will focus on technical conferences in the Houston, Texas and New Orleans, Louisiana areas. It is anticipated that presentations and/or papers will be completed at the beginning, middle, and end of the project. Amoco does not intend to regard any data and/or information on this project as proprietary. 
FIGURES AND TABLES 


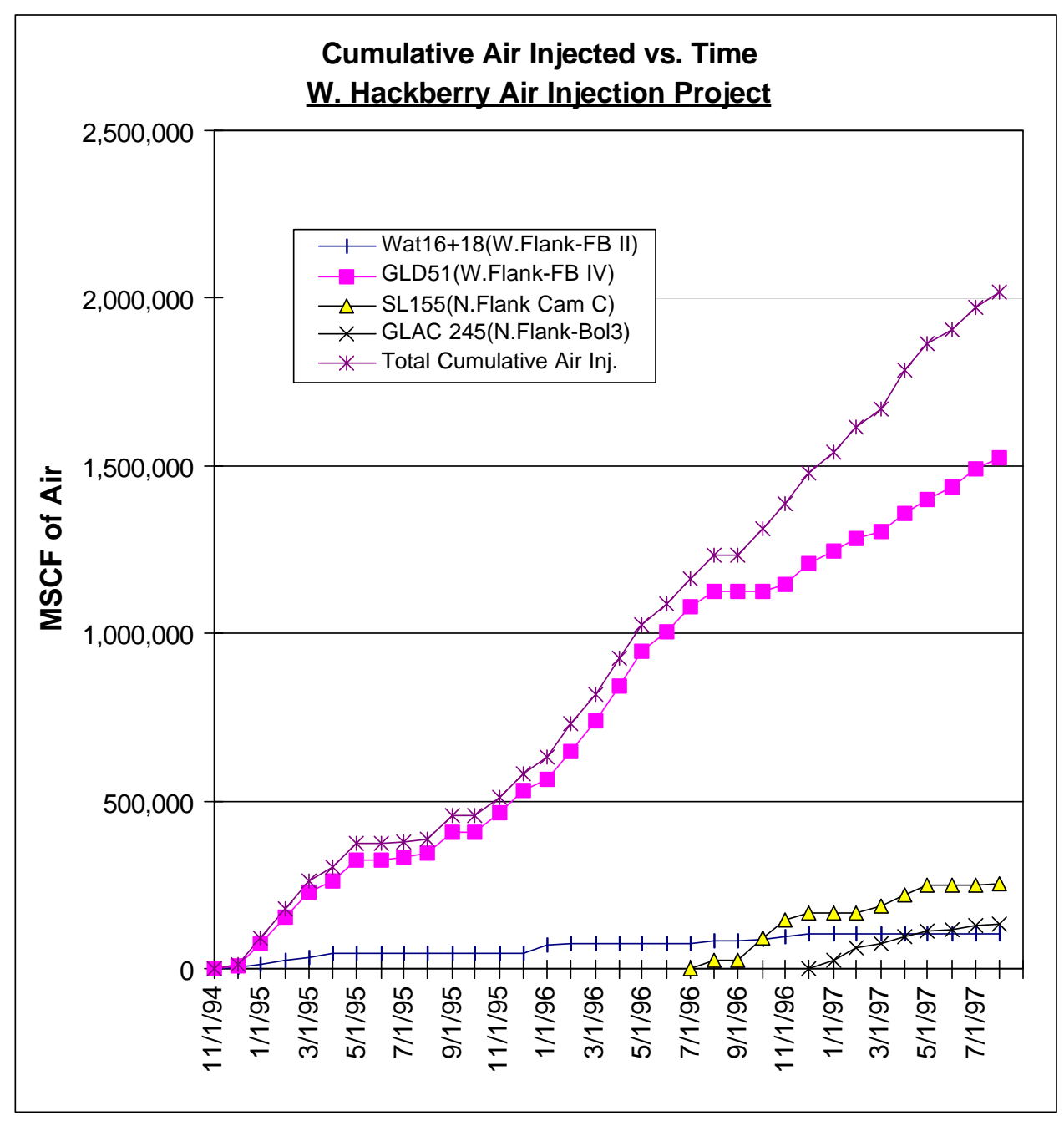




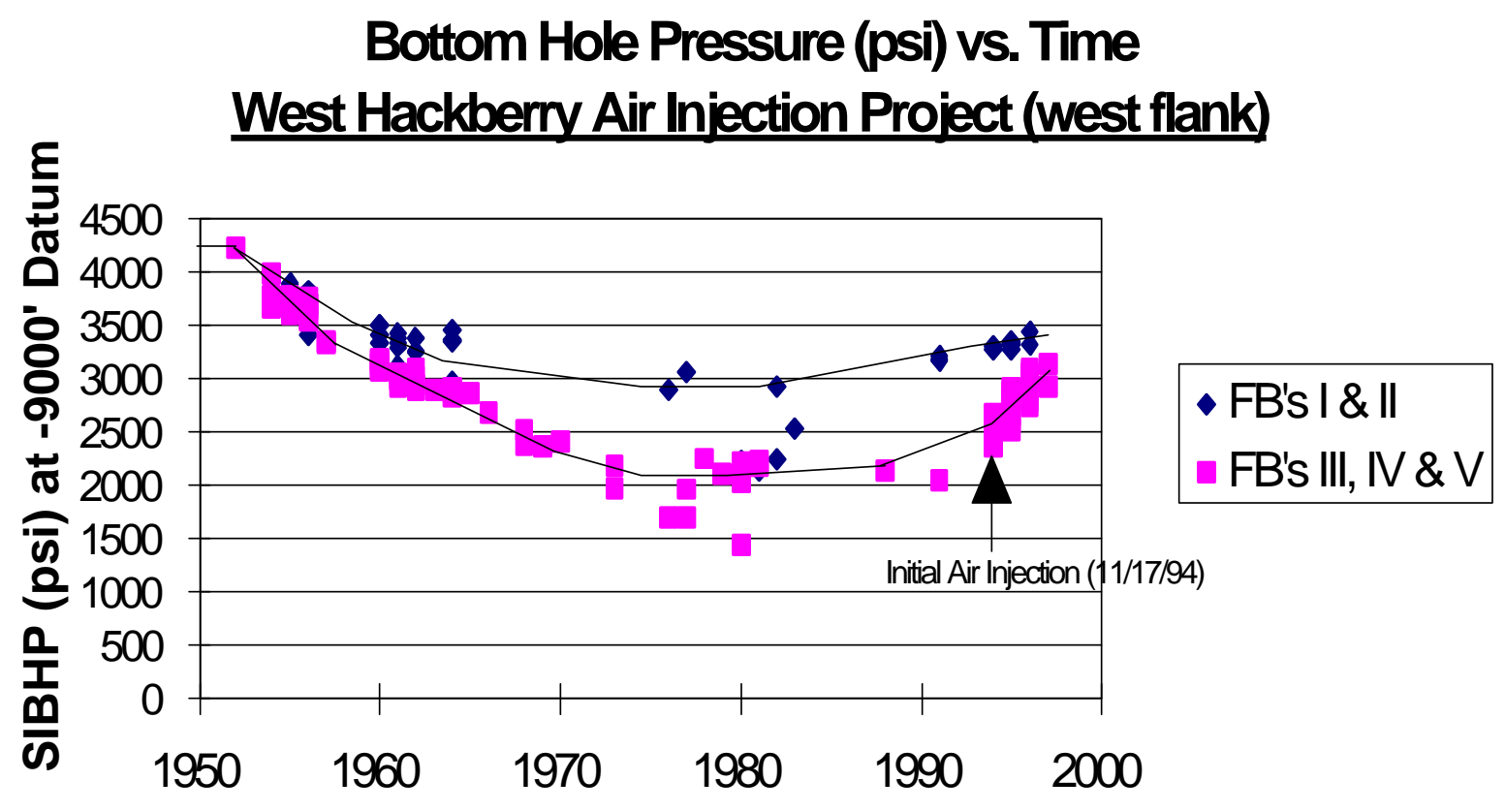




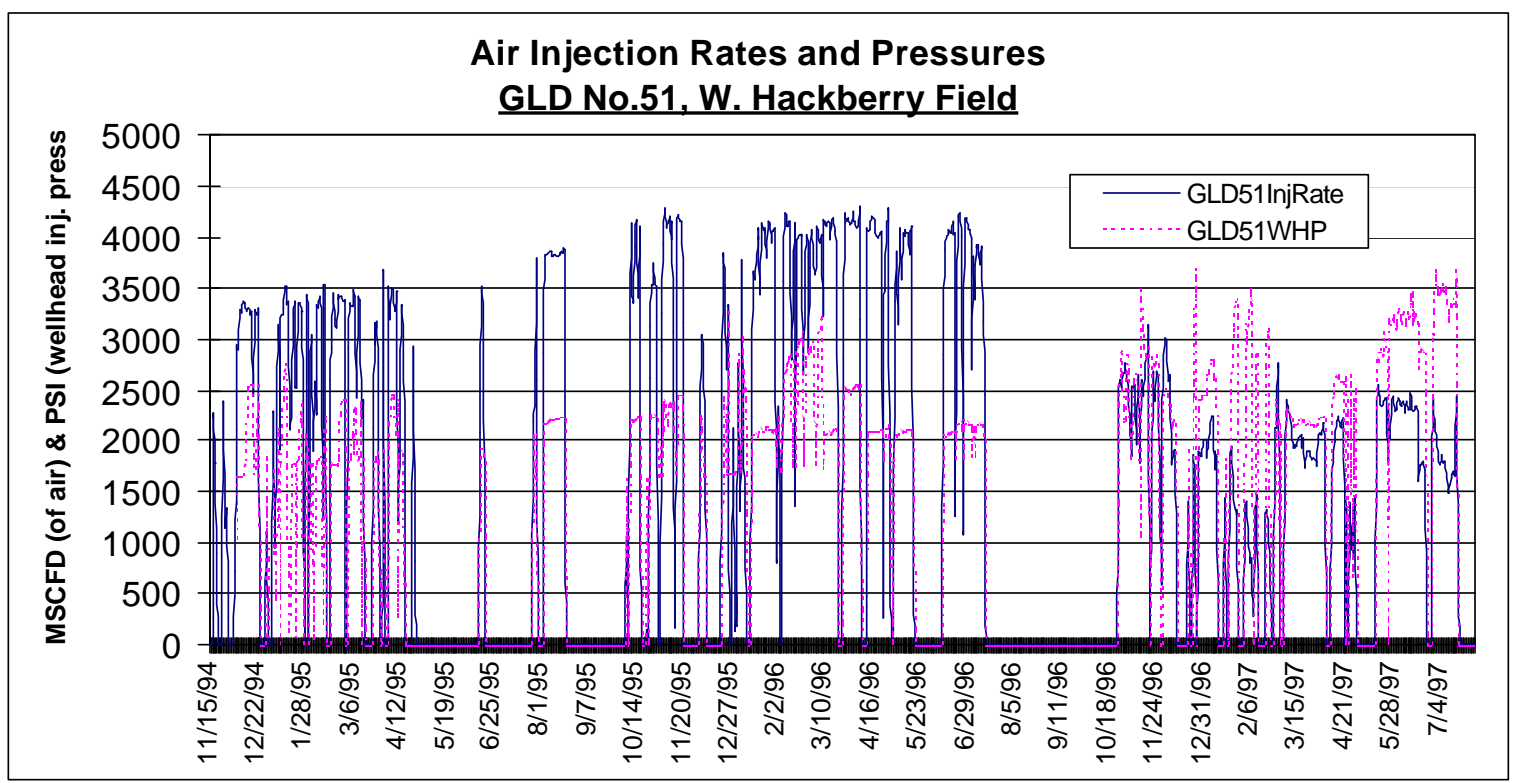



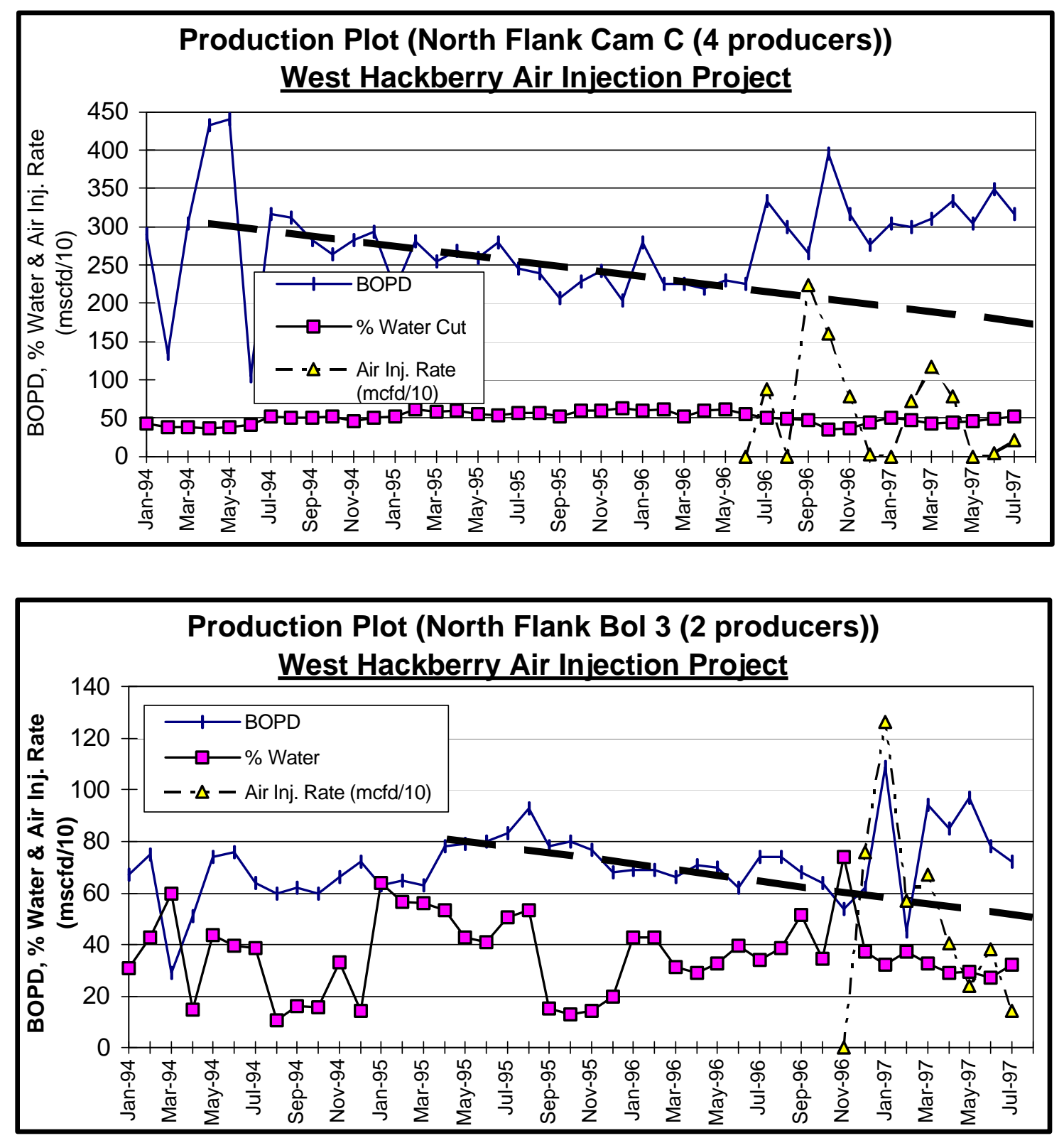


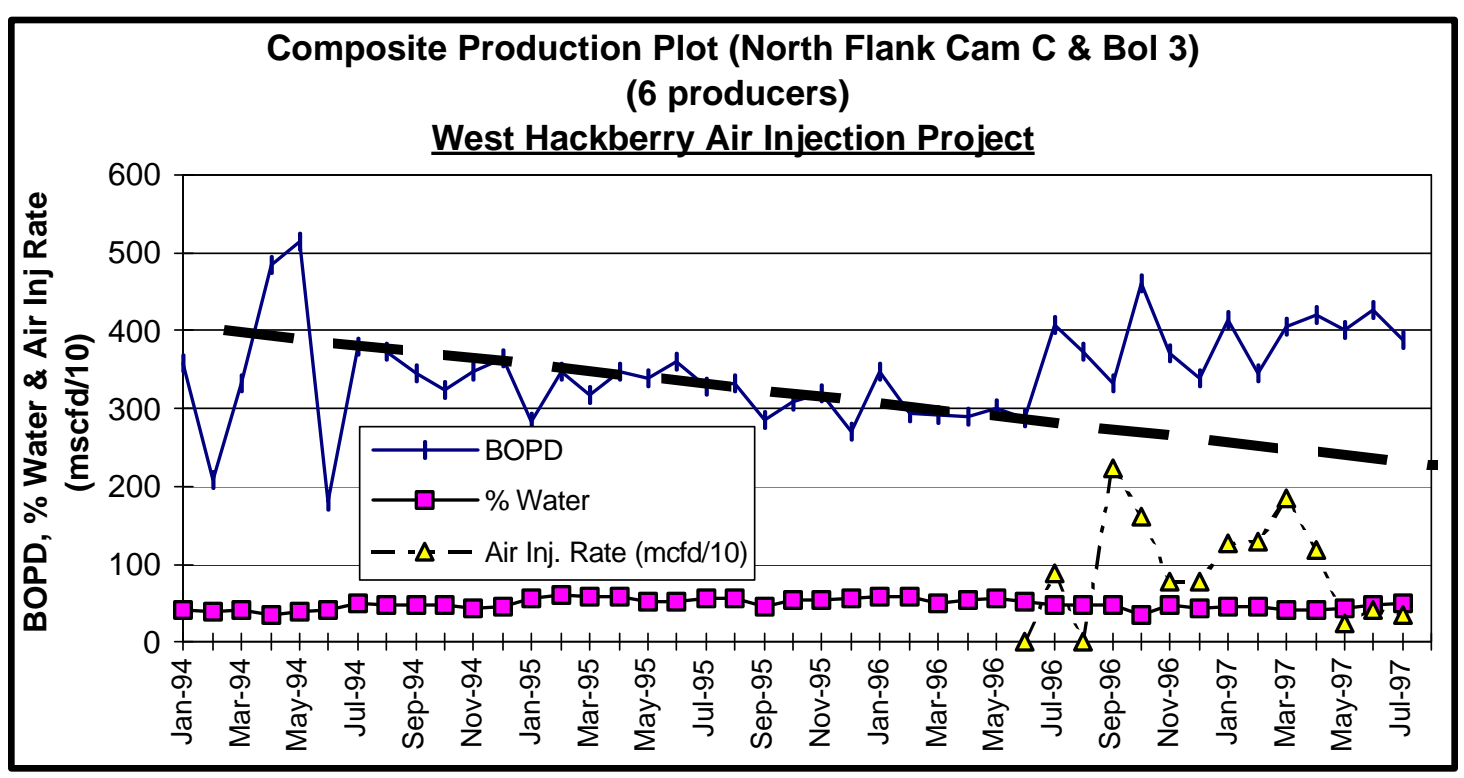

\section{Sample Economics for Low Pressure Air Injection (assumes purchased compressed air)}

Incremental Oil (bbls)

$x(1-1 / 6$ royalty $)$

$x(1-1 / 8$ severance tax $)$

$x$ Price of Oil( $\$ 20 / \mathrm{bbl})$

-Cost of Facilities

-Well Conversions

-Repair Well Expense

-Cost of Air

(392 mmcf at $\$ 0.49 / \mathrm{mcf}$ )

Total(July,96-July,97)
58,500 From July, 96 to July, 97

0.833

0.875

$\$ 20$

$\$ 853,000$

$(\$ 280,000)$ (downstream of compressors)

$(\$ 40,000)$

$(\$ 20,000)$

$(\$ 192,000)$ (includes $\$ 2 / \mathrm{mmbtu}$

for natural gas fuel)

$\$ 321,000$ before tax incremental cash flow


Schematic Cross-Section of North Flank Cam C Reservoir (WH Cam C RB SU a.k.a. Reservoir A)

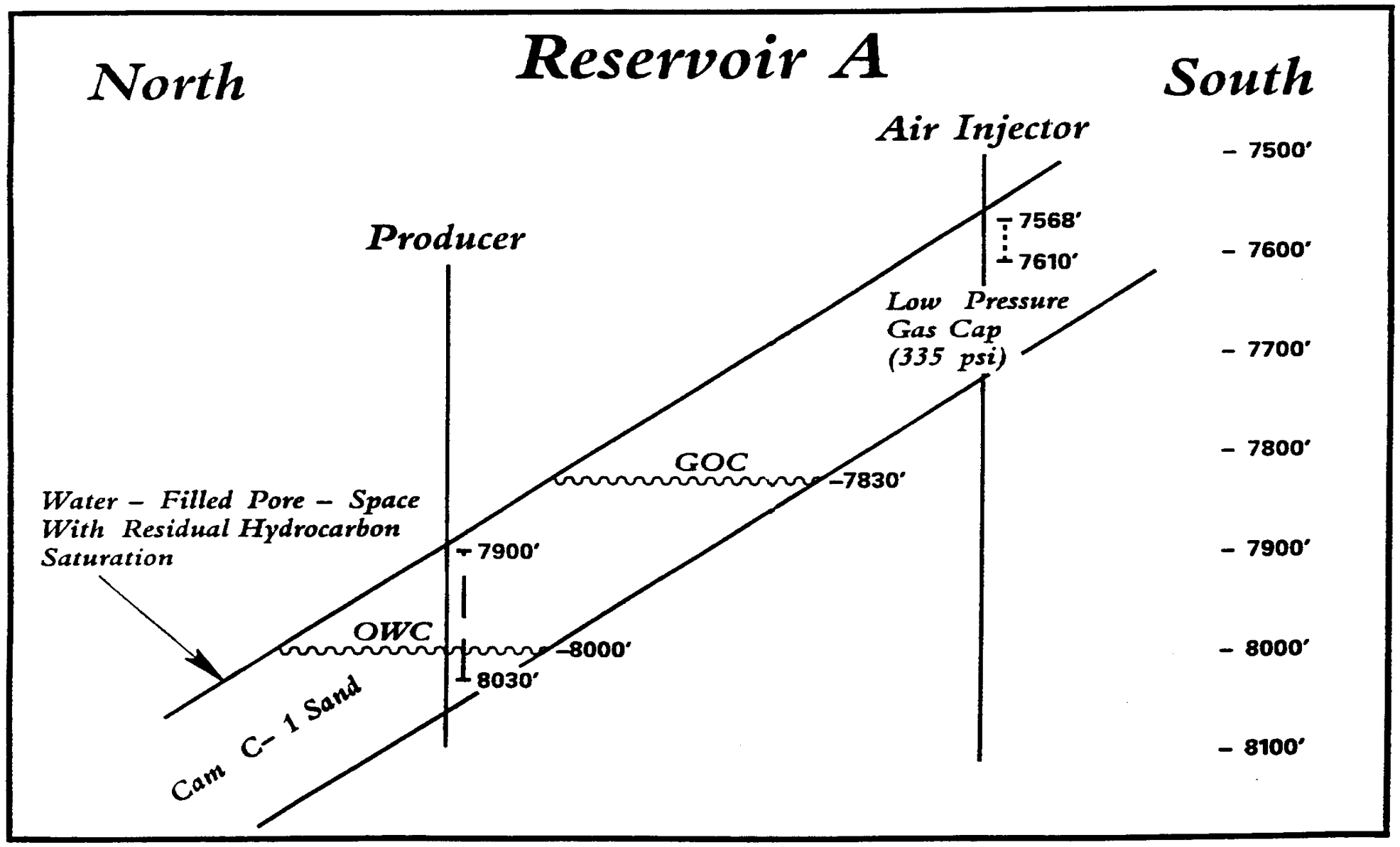

Figure 3 


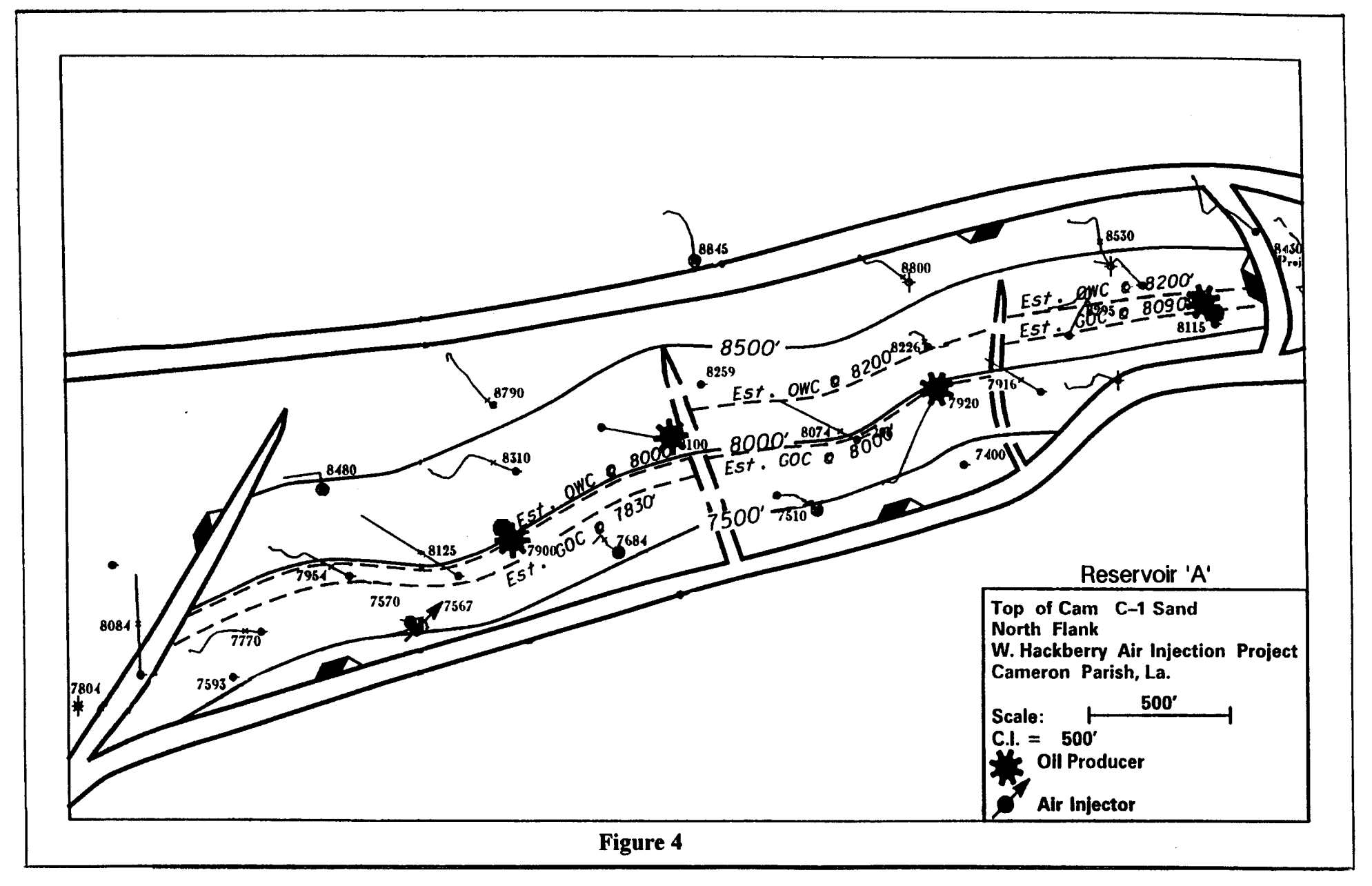




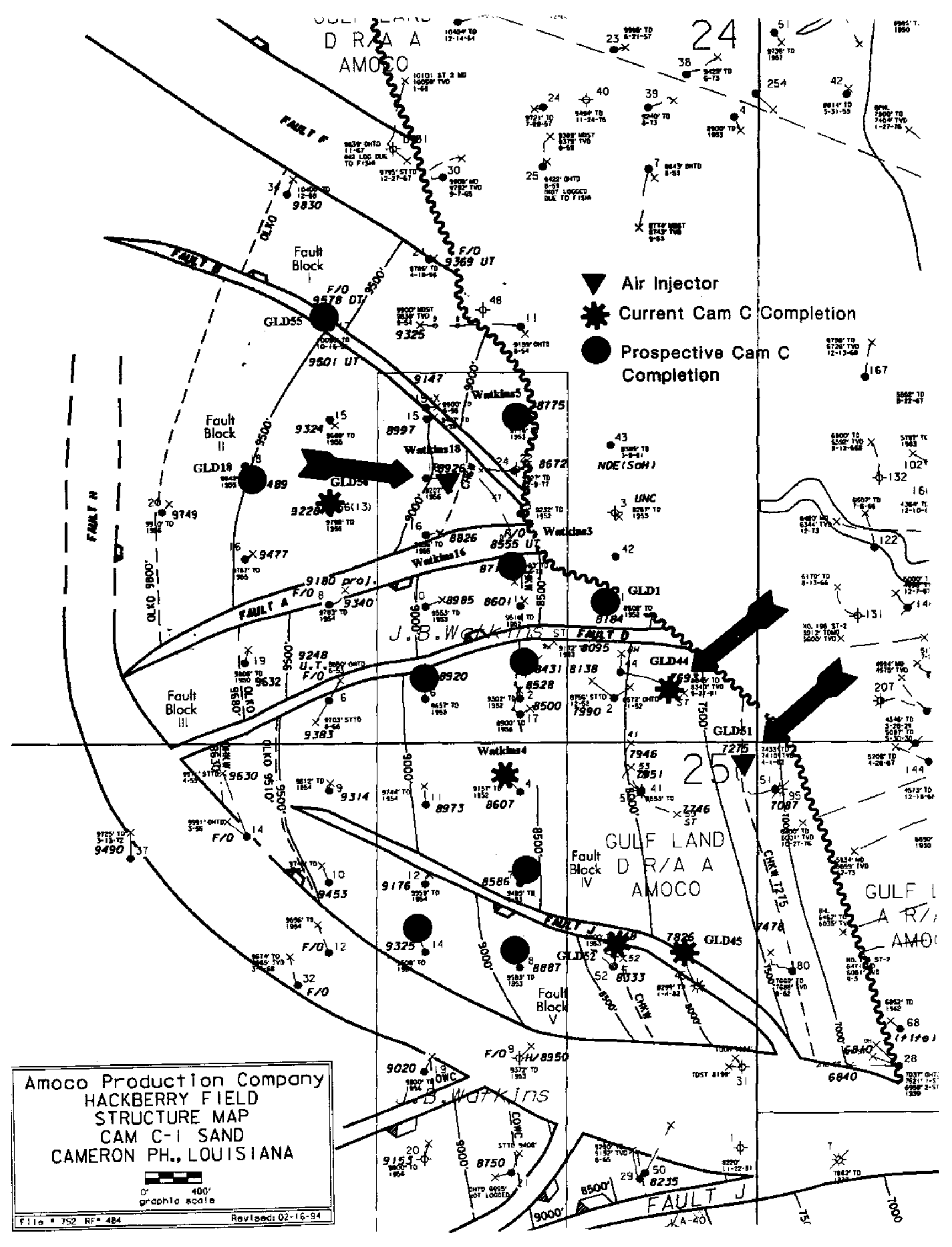

Structure Map for the Top of the Cam C-1 sand on the West Flank 